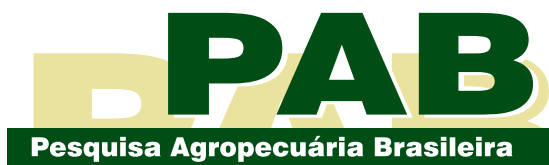

ISSN 1678-3921

Journal homepage: www.embrapa.br/pab

For manuscript submission and journal contents, access: www.scielo.br/pab

Ivan Ricardo Carvalho(1凶) (iD,

Vinícius Jardel Szareski(2) (iD),

José Antônio Gonzalez da Silva(1) (iD,

Andrei Caíque Pires Nunes(3) (D),

Tiago Corazza da Rosa(2) (ID,

Maurício Horbach Barbosa(2) (iD,

Deivid Araújo Magano(1) (iD,

Giordano Gelain Conte ${ }^{(1)}(\mathrm{D}$,

Braulio Otomar Caron ${ }^{(4)}$ iD and

Velci Queiróz de Souza(5) (iD)

(1) Universidade Regional do Noroeste do Rio Grande do Sul, Departamento de Estudos Agrários, Avenida do Comércio, no 3.000 , Bairro Universitário, CEP 98700-000 ljuí,

RS, Brazil.

E-mail: carvalho.irc@gmail.com

jose.gonzalez@unijui.edu.br.

deivid.magano@unijui.edu.br

gioogc@gmail.com

(2) Universidade Federal de Pelotas, Avenida Eliseu Maciel, s/no, CEP 96160-000 Capão do Leão, RS, Brazil.

E-mail: viniciusszareski@gmail.com,

tiagocorazza@live.com,

hbmauricio@yahoo.com.br

(3) Universidade Federal do Sul da Bahia, Centro de Formação em Ciências Agroflorestais, CEP 45613-204 Itabuna, BA Brazil.

E-mail: andreicaiquep@gmail.com

(4) Universidade Federal de Santa Maria, Linha 7 de Setembro, BR-386, Km 40, CEP 98400-000 Frederico Westphalen, RS, Brazil.

E-mail: otomarcaron@gmail.com

(5) Universidade Federal do Pampa, Rua 21 de abril, o 80, CEP 96450-000 São Gabriel, RS, Brazil.

E-mail: velciq@gmail.com

${ }^{\bowtie}$ Corresponding author

Received

February 5, 2018

Accepted

April 14, 2020

How to cite

CARVALHO, I.R.; SZARESKI, V.J.; SILVA J.A.G. da; NUNES, A.C.P.; ROSA, T.C. da; BARBOSA, M.H.; MAGANO, D.A.; CONTE, G.G.; CARON, B.O.; SOUZA, V.Q. de. Multivariate best linear unbiased predictor as a tool to improve multi-trait selection in sugarcane. Pesquisa Agropecuária Brasileira, v.55, e00518, 2020. DOI: https://doi.org/10.1590/ S1678-3921.pab2020.v55.00518.

\section{Multivariate best linear unbiased predictor as a tool to improve multi-trait selection in sugarcane}

\begin{abstract}
The objective of this work was to evaluate the use of the multivariate best linear unbiased predictor (BLUP) method for multi-trait selection, to estimate the genetic parameters in sugarcane (Saccharum officinarum) genotypes. The experiment was carried out in a randomized complete block design with 21 sugarcane genotypes, in seven crop years, in a factorial arrangement with three replicates. The measured traits were: total yield of stems per hectare, total volume of juice per hectare, production of total soluble sugars, and stem length. The source variation in the crop years strongly contributed for the obtention of the expected values of the sum of squares, without causing distortions in the variance components and genetic variables. The measured traits showed genetic variability and allowed of efficient univariate and multivariate selections. The highest selection efficiency was obtained by using more than eight measurements, since they favored the estimates of heritability, accuracy, and repeatability. The 'IAC873396', 'Nova Iraí', 'IACSP 93-6006', and 'RB 835089' genotypes were superior as to the traits tested, regardless of the crop year. The BLUP multivariate technique for multi-trait selection is robust and allows of the increasing of the selection gains, accuracy, and reliability of predictions for sugarcane breeding.
\end{abstract}

Index terms: Saccharum officinarum, multi-trait selection, multivariate models, repeatability.

\section{Melhor preditor multivariado linear não viesado como ferramenta para a seleção multicaracterísticas em cana-de-açúcar}

Resumo - O objetivo deste trabalho foi avaliar o uso do método multivariado de melhor preditor linear não viesado (BLUP), para estimar os parâmetros genéticos em genótipos de cana-de-açúcar (Saccharum officinarum). O experimento foi realizado em delineamento de blocos ao acaso, com 21 genótipos de canade-açúcar, em sete anos agrícolas, em arranjo fatorial com três repetições. As características medidas foram: rendimento total de caules por hectare, volume total de suco por hectare, produção de açúcares solúveis totais e comprimento do caule. A variação da fonte nos anos agrícolas contribuiu fortemente para a obtenção dos valores esperados da soma dos quadrados, sem causar distorções das estimativas dos componentes de variância e parâmetros genéticos. As características medidas apresentaram variabilidade genética e permitiram seleções univariada e multivariada eficientes. A maior eficiência de seleção foi obtida com o uso de mais de oito medições, pois elas favoreceram as estimativas de herdabilidade, precisão e repetibilidade. Os genótipos 'IAC873396', 'Nova Iraí', 'IACSP 93-6006' e 'RB 835089' foram superiores para as características testadas, independentemente do ano agrícola. A técnica multivariada BLUP para a seleção multicaracterísticas é robusta e permite aumentar os ganhos de seleção, a acurácia e a confiabilidade das predições para o melhoramento da cana-de-açúcar.

Termos para indexação: Saccharum officinarum, seleção multicaracterísticas, modelos multivariados, repetibilidade. 


\section{Introduction}

Brazil stands out as the largest producer of sugarcane (Saccharum officinarum) worldwide (FAO, 2017). Currently, nearly nine million hectares of sugarcane is established in Brazil, with 657 million tons of phytomass production. The volume of national production is highly influenced by the Southeast region expressiveness, which represents $65 \%$ of it, followed by the Midwest (21\%), Northeast (7\%), South $(6 \%)$, and North (1\%) regions (Acompanhamento..., 2016).

The sugarcane cultivation requires some specific edaphoclimatic conditions, in order to achieve high yields, and maximize the use of available resources. This crop requires $1,500 \mathrm{~mm}$ of rainfall (Neupane $\&$ Guo, 2019). The maximum yield requires thermal amplitude between $20^{\circ} \mathrm{C}$ and $38^{\circ} \mathrm{C}$, which is considered the optimal range for growth and development of the plants. Sugarcane has a large capacity of extracting soil nutrients such as potassium, nitrogen, calcium, magnesium, phosphorus, sulfur, iron, zinc, manganese, and boron (Silva \& Silva, 2012).

Brazilian growing regions show many varied conditions and edaphoclimatic features; therefore, there is a need to identify which genotypes are superior for yield, quality, and yield stability. To maximize the success of genetic breeding programs, the use of the multi-trait index has been applied in plant breeding and has led to an increase in the selection efficiency of traits desirable, looking for economically important traits (Pelegrin et al., 2017). Similarly, genetic gains in sugarcane breeding programs are dependent on the choice of traits, the magnitude of heritability, and the spatial and temporal repeatability of these parameters (Eeuwijk et al., 2019).

A strategy to solve questions on cultivar selections is based on the adoption of mathematical models. In this sense, according to Vittorazzi et al. (2017), the best linear unbiased prediction (BLUP) is a standard method for estimating the random effects of a mixed model. This method was originally developed in animal breeding, for the estimation of breeding values. It is now widely used in many areas of research. However, there are no reports on the use of a BLUP multivariate selection, to estimate a joint value of heritability for sugarcane. The use of this approach could allow of the selection of sugarcane genotypes with greater efficiency, adaptability, and stability. It performs better than other conventional methods, such as linear models, nonlinear models, regression bi-segmented models, and it is also better than methods combining additive effects and multiplicative interactions that could not describe the behavior of multi-trait quality with excellent fit for sugarcane production.

The objective of this work was to evaluate the multivariate best linear unbiased predictor method (BLUP) for a multi-trait selection to estimate the genetic parameters in sugarcane genotypes.

\section{Materials and Methods}

The study was carried out in the experimental area of the Universidade Federal de Santa Maria, Campus Frederico Westphalen (27039'56"S, 53²4' $94^{\prime \prime} \mathrm{W}$, at 490 $m$ altitude), in the state of Rio Grande do Sul, Brazil, in seven crop years - 2010, 2011, 2012, 2013, 2014, 2015, and 2016 (Table 1).

The soil of the experimental area is classified as a Latossolo Vermelho distrófico típico (Oxisols) according Santos et al., (2018). The climate, according to the Köppen-Geiger's classification, is a subtropical Cfa.

The experimental design was in a randomized complete block, in a factorial arrangement, with seven crop year cultivations $\times 21$ sugarcane genotypes, with three replicates (Table 1).

The following traits were measured between August $15^{\text {th }}$ and September $7^{\text {th }}$, in each one of the seven crop years: total yield of stems per hectare (TYSH); total volume of juice per hectare (TVJH); production of total soluble sugars (PTSS); and stem length (LENG). The TYSH was obtained by count, harvest, and determination of the mass of the total number of stems per experimental unit. Then, calculations were performed for the ratio between total mass of stems per experimental unit, and the number of stems. The results $\left(\mathrm{Mg} \mathrm{ha}^{-1}\right)$ were adjusted to the population density employed.

For TVJH, the stems harvested in the experimental unit were cleaned and milled, and the magnitude of the liquid extracted was measured in a graduated cylinder. The results obtained for juice yield per stem $\left(\mathrm{L} \mathrm{ha}^{-1}\right)$ were adjusted to the population density employed.

For PTSS, the stems located in the useful area of the experimental unit were selected, and two 
representative stems were chosen, which were sent to the laboratory for evaluation of the Brix degree by an analogical refractometer RHB62 (AKSO Measurement Instruments, São Leopoldo, RS, Brazil), at the basal, medium and superior portion of each stem. After this evaluation, the results $\left(\mathrm{kg} \mathrm{ha}^{-1}\right)$ were adjusted through the magnitude of juice per unit of area.

The LENG was evaluated by measuring 10 stems (cm) from their basal (cutting point) to the apical extremity (point of meristems differentiation) per experimental unit. All growing treats were carried out in a standardized way for the crop years, and the experimental units were constituted by five lines of plants spaced at $1.2 \mathrm{~m}$, with $6 \mathrm{~m}$ length, which resulted in a population density of 25,000 viable plants $\mathrm{ha}^{-1}$.

The data were subjected to the analysis of variance, at $5 \%$ of probability, in order to verify the assumptions of the model (Ramalho et al., 2012). Subsequently, the joint analysis was carried out to identify the presence of interaction between the crop year cultivations $x$ sugarcane genotypes at $5 \%$ of probability. The traits that showed significant interactions were subjected to the method of the relative contribution for interaction of the mean-square expected values, in order to understand which levels of treatment are determinant for the significance of the results (Carvalho et al., 2017). Subsequently, a multi-trait index was applied, combining the TYSH and PTSS effects, since these traits show a similar economic importance and should be selected simultaneously. Later, a multi-trait phenotypic index with a single tendency (Nunes et al., 2017) was calculated with the following equation:

$$
\mathrm{PI}=\left(\mathrm{TYSH} / \mathrm{S} \_\mathrm{TYSH}\right) \times\left(\mathrm{PTSS} / \mathrm{S} \_ \text {PTSS }\right)
$$

Table 1. Crop years and sugarcane genotypes evaluated in the experimental area.

\begin{tabular}{cccc}
\hline Year & \multicolumn{3}{c}{ Genotype } \\
\hline 2010 & $\mathrm{G}_{1}$ (IACSP 93-6006) & $\mathrm{G}_{8}$ Nova Iraí & $\mathrm{G}_{15}$ Preguiçosa \\
2011 & $\mathrm{G}_{2}$ IAC91-2218 & $\mathrm{G}_{9}$ Ligeirinha Roxa & $\mathrm{G}_{16}$ Tucumã \\
2012 & $\mathrm{G}_{3}$ IAC87-3396 & $\mathrm{G}_{10}$ Pernambucana & $\mathrm{G}_{17}$ Pingo de Mel \\
2013 & $\mathrm{G}_{4}$ IAC91-5155 & $\mathrm{G}_{11}$ SP716163 & $\mathrm{G}_{18}$ Palhuda \\
2014 & $\mathrm{G}_{5}$ IAC91-2195 & $\mathrm{G}_{12}$ RB 785750 & $\mathrm{G}_{19}$ IAC873396 \\
2015 & $\mathrm{G}_{6}$ RB 855453 & $\mathrm{G}_{13}$ NA 56792 & $\mathrm{G}_{20}$ RB 835089 \\
2016 & $\mathrm{G}_{7}$ RB 85506 & $\mathrm{G}_{14}$ IAC915035 & $\mathrm{G}_{21}$ RB 765418 \\
\hline
\end{tabular}

The data were subjected to the deviance analysis, at $5 \%$ of probability, by the chi-square test (Resende, 2007), which bases the significance and reliability of parameters obtained by mixed statistical models. Subsequently, the components of variance and the genetic parameters were estimated through the restricted maximum likelihood method (REML), by the statistical model

$$
\mathrm{Y}=\mathrm{Xr}+\mathrm{Zg}+\mathrm{Wi}+\mathrm{e},
$$

in which: $Y$ refers to the data vector of each trait; $r$ is the effect of replicates (fixed); $g$ is the effect of genotypes (random); i is the effect attributed to the interaction genotypes $\times$ environments (random); and e represents the residues (random).

This approach allowed of the following estimations for: the individual broad sense heritability $\left(\hat{h}^{2} \mathrm{~g}\right)$; repeatability of the parameter (r); coefficient of determination of the permanent effects $\left(\mathrm{C}^{2}\right.$ perm); coefficient of determination for the genotype $\times$ crop year interaction $\left(\mathrm{C}^{2} \mathrm{gm}\right)$; genotypic correlation between the crop years (rgmed); the broad sense heritability free from the effects of the interaction genotypes $x$ crop years ( $\left.\hat{\mathrm{h}}^{2} \mathrm{mg}\right)$; the accuracy (Ac); and the overall mean of the traits.

The definition of the genetic parameters made it possible to use the best linear unbiased predictor (BLUP) method to predict the genetic values (Henderson, 1975). This allowed of the ranking of the genotypes through the multi-trait phenotypic index (PI), and, then, the TYSH, TVJH, PTSS, LENG, and the phenotypic index (TYSH $\times$ PTSS) used to compose the genetic index of the selection, which is derived from the five conjugated traits, based on the following equation:

$$
\mathrm{GI}=\mathrm{b}_{1} g \mathrm{go}+\mathrm{b}_{2} \mathrm{ga}_{1}+\mathrm{b}_{3} \mathrm{ga}_{2}+\mathrm{b}_{4} \mathrm{ga}_{3}+\mathrm{b}_{5} \mathrm{ga}_{4}
$$

in which: GI represents the multi-trait genetic index; go represents the standardized genotypic value for the objective trait $(\mathrm{PI}=\mathrm{TYSH} \times \mathrm{PTSS})$; and gai represents the standardized genotypic value of the auxiliary traits (TYSH, TVJH, PTSS and LENG). The weighting coefficients (bi) of the index are given by Viana \& Resende (2014) by the equation b $=\mathrm{P}-1 \mathrm{C}$, in which: 


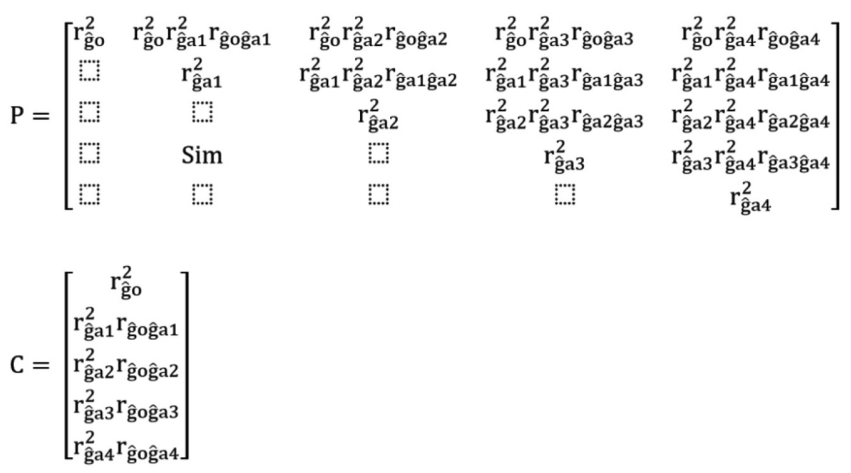

After defining the parameters, the genetic covariance between the predicted genetic value of the trait PI $($ TYSH $\times$ PTSS) and the five informational traits that represent the predicted genetic values standardized the target (PI) and auxiliary traits (TYSH, TVJH, PTSS and LENG), in which: $\mathrm{r}\left(\mathrm{g}^{\wedge} \mathrm{o}\right)^{2}$ represents the reliability of the selection based on the objective trait (PI); r(gal) ${ }^{2}$ evidences the reliability of selection based on the auxiliary trait TYSH; $r\left(g \hat{a}_{2}\right)^{2}$ is the reliability of selection based on the auxiliary trait TVJH; $r\left(g^{\wedge}{ }^{\wedge} \hat{a}_{1}\right)$ represents the genetic correlation between the objective trait and the auxiliary trait TYSH; $r\left(g{ }^{\wedge} \hat{~}^{\wedge} a_{2}\right)$ refers to the genetic correlation between the objective trait (PI) and the auxiliary TVJH; and $\mathrm{r}\left(\mathrm{g} \hat{\mathrm{a}} \mathrm{lg} \mathrm{a}_{2}\right)$ is evidenced as the genetic correlation between the two auxiliary traits. The reliability of the index is given by the ratio between the variance of the index (GI) and the genetic variance of the PI trait as $\mathrm{rgg}^{2}=\operatorname{Var}$ (index) $/ \sigma \mathrm{g}^{2}$, with the standardization of the predicted genetic values, $\sigma \mathrm{g}^{2}=1$ andrgg ${ }^{2}=\operatorname{Var}$ (index). Therefore, the index variance is given by $\operatorname{Var}($ index $)=b^{\prime} \mathrm{Pb}$.

Consequently, the accuracy of GI is given by the square root of the reliability. In order to correlate the rankings of the genotypes using the multi-trait approach, through the phenotypic index (PI), the predicted genotypic value $(\mathrm{u}+\mathrm{g})$ was employed with the genotypic value added to the average interaction $(\mathrm{u}+\mathrm{g}+\mathrm{gem})$. This operation made it possible to express the estimates of stability (MHVG), adaptability (PRVG), as well as to express simultaneously those of stability, adaptability, and yield (MHPRVG*MG). These combined procedures evidenced the presence of variability for the genotype ranking. To perform the statistical analyses, the software's SAS (SAS Institute Inc., Cary, NC, USA), Genes (Cruz, 2013), R (R Core Team, 2015), and Selegen (Resende, 2007) were used.

\section{Results and Discussion}

There was a significant interaction between crop years and sugarcane genotypes. The traits TYSH, TVJH, and PTSS showed no interaction between the different sources of variability. However, there was an intrinsic variability for principal effects by crop years and sugarcane genotypes (Table 2). Due to the method of the relative contribution of expected values of the sum of squares for the interaction based on the presence of simple effects, its use was possible only for the LENG trait. The 'IACSP 93-6006' (G1), 'IAC87-3396' (G3), 'IAC91-5155' (G4), 'Nova Iraí' (G8), 'Pernambucana' (G10), 'Preguiçosa' (G15), and 'IAC873396' (G19) genotypes contributed 6.1\% average for the effects of genotype $\times$ environment interactions. Probably, these genotypes express abrupt variations of plant growth and development. In contrast, the 'RB 855453' (2.6\%), 'SP716163' (3.4\%) and 'RB 765418' $(2.80 \%)$ genotypes showed the lower contributions for the interaction of expected values of the sum of

Table 2. Variance analysis for the traits total yield of stems per hectare (TYSH), total volume of juice per hectare (TVJH), production of total soluble sugars (PTSS), and stem length (LENG) measured in sugarcane genotypes grown in seven crop years.

\begin{tabular}{lcrrr}
\hline \multirow{2}{*}{ Variation source } & \multicolumn{3}{c}{ Mean square } \\
\cline { 2 - 5 } & \multicolumn{1}{c}{ TYSH $^{+}$} & TVJH & PTSS & LENG \\
\hline Crop years (CY) & $19,881,168,178.0^{*}$ & $4,210,541,180.0^{*}$ & $180,679,417.0^{*}$ & $121,167.14^{*}$ \\
Genotypes (G) & $1,022,692,925.9^{*}$ & $249,779,591.0^{*}$ & $4,975,824.0^{*}$ & $4,360.76^{*}$ \\
CYx G & $348,743,143.8$ & $87,635,847.0$ & $2,181,938.0$ & $1,014.38^{*}$ \\
Block & $2,258,774,785.4^{*}$ & $4,068,244,430.0^{*}$ & $10,174,882.0^{*}$ & $1,029.96$ \\
\hline CV (\%) & 49.13 & 53.78 & 55.74 & 18.07 \\
\hline
\end{tabular}

*Significant by the F-test, at $5 \%$ of probability. 
squares. These genotypes were considered most stable phenotypically, whereas, stem length showed a lower phenotypic plasticity.

The crop years 2011, 2013, and 2015 contributed $18.1 \%$ for the effects of genotypes $\times$ environments interactions. These results are essential to understand the abrupt effects on phenotypic modification of traits caused by edaphoclimatic variations of growing environments. Although the present study is based on seven crop years, using sugarcane clones, an oscillation in the magnitude was verified, which influences the estimation and repeatability of parameters of interest.

There were significance and reliability for the variance components and genetic parameters obtained by the REML method for TYSH, PTSS, LENG and PI (Table 3). The highest magnitudes of individual broad sense heritability $\left(h^{2} g\right)$ were obtained through the LENG. These estimates are indicative of the presence of genetic variability available for selection among the studied genotypes.

For all traits, the magnitudes of estimates increased, except for the broad-sense parameter heritability free from the effects of the interaction genotypes $\times$ crop years $\left(\hat{h}^{2} \mathrm{mg}\right)$. These results show that there is an inclination to $\mathrm{h}^{2} \mathrm{~g}$. The magnitudes of $\mathrm{mg}^{2} \mathrm{mg}$ showed up higher than $\mathrm{h}^{2} \mathrm{~g}$ because that crop year has exerted

Table 3. Estimates of genetic parameters (REML) for the multi-trait phenotypic index (PI), total yield of stems per hectare (TYSH), total volume of juice per hectare (TVJH), production of total soluble sugars (PTSS), and stem length (LENG), measured in 21 sugarcane genotypes grown in seven crop years.

\begin{tabular}{lccccc}
\hline $\begin{array}{l}\text { Genetic } \\
\text { parameter }\end{array}$ & PI & TYSH & TVJH & PTSS & LENG \\
\hline$\hat{\mathrm{h}}^{2} \mathrm{~g}$ & 0.04 & 0.05 & 0.05 & 0.04 & 0.14 \\
$\mathrm{r}$ & 0.08 & 0.17 & 0.15 & 0.1 & 0.23 \\
$\mathrm{c}^{2}$ perm & 0.04 & 0.12 & 0.1 & 0.06 & 0.09 \\
$\mathrm{c}^{2}$ gm & 0.01 & 0.05 & 0.03 & 0.04 & 0.16 \\
rgmed & 0.73 & 0.51 & 0.6 & 0.52 & 0.48 \\
$\mathrm{~h}^{2}$ mg & 0.37 & 0.34 & 0.35 & 0.34 & 0.6 \\
Accuracy & 0.61 & 0.59 & 0.59 & 0.59 & 0.77 \\
\hline Average & 2.5 & 37.25 & $17,492.3$ & $2,591.03$ & 142.84 \\
\hline
\end{tabular}

$\hat{\mathrm{h}}^{2} \mathrm{~g}$, coefficient of individual broad-sense heritability; r, repeatability; $\mathrm{C}^{2}$ perm, coefficient of determination of permanent effects; $\mathrm{C}^{2} \mathrm{gm}$, coefficient of determination of the effect interactions between genotypes and crop years; rgmed, genotypic correlation between crop years; $\hat{\mathrm{h}}^{2} \mathrm{mg}$, broad-sense heritability free from the effect interactions between genotypes and crop years; accuracy, genetic accuracy; average, overall mean of the traits. on traits under the phenotypic manifestation for the 7 years in evaluation. Usually, the genetic breeding involves only the phenotypic manifestation of traits, which is of extreme importance to identify and quantify the effects of crop years, or growing environments, on the phenotype, allowing of achieving estimates and reliable predictions of the genetic value of certain genotype. In this study, the traits YSH, PTSS, and LENG were considered more stable throughout the breeding generations, irrespectively of the repeatability of genetic parameters.

Regarding repeatability, Pelegrin et al. (2017), classified as high $(r>0.60)$, intermediate $(0.30<r<0.60)$, and low $(r<0.30)$. According to this classification, all measured traits showed low repeatability in the present study. The increment of a trait's repeatability maximizes the precision of selection strategies. Both the coefficient of determination of the permanent effects $\left(\mathrm{c}^{2}\right.$ perm) and the coefficient of determination of the genotypes $\times$ environments interaction effects $\left(c^{2} \mathrm{gm}\right)$ are low, indicating that intrinsic features of each crop year influence these sugarcane genotypes. Therefore, the phenotypic plasticity of this crop should be considered.

The obtained estimates showed moderate but reliable accuracies due to the study's representativeness. Resende \& Duarte (2007) classified the accuracy according to its magnitudes as of low precision $(A c<0,50)$, moderate $(A c \geq 0,50)$, high $(A c \geq 0.70)$, and very high $(A c \geq 0.90)$. According to Della Bruna et al. (2012), higher-accuracy magnitudes for traits of interest increase the confidence in the prediction of a genotype's genetic value.

When the efficiency was analyzed for the number of measurements, or evaluations (m) performed in the present work, it was observed that the estimate efficiency (EF) incremented with the increase of the number of measurements, and this made it possible to obtain a plateau after eight measurements. The estimated efficiency (EF) is represented by the maximization of broad-sense heritability, free from the effects of genotypes $\times$ environments interaction, looking for repeatability, and higher accuracy. In this sense, when at least 8 to 10 measurements (m) are performed, it is possible to obtain a plateau of accuracy and, then, potentiate the repeatability of genetic parameters along the crop years of sugarcane crop (Table 4). 
All magnitudes were higher than $\mathrm{rg}=0.95$, which is a clue that multi-trait selection can be used irrespectively of the crop year. However, PI magnitudes would be predominantly affected by genetic effects. Regardless of the crop year, the genotypes considered ideal were those that showed a positive individual gain with the PI overall mean in the experiment, which made it possible to select ten genotypes (Table 5).

Gains of 29.68\% were observed in 'IAC873396'(G19), that was the best ranked genotype in the simultaneous selection for increasing the total yield of stem per hectare and the production of total soluble sugars. The selection gains in the comparison of the effects

Table 4. Genetic correlations among crop years referring to the multi-trait phenotypic index (PI).

\begin{tabular}{|c|c|c|c|c|c|c|c|}
\hline Crop year & 2010 & 2011 & 2012 & 2013 & 2014 & 2015 & 2016 \\
\hline 2010 & 1.00 & 0.99 & 0.99 & 0.99 & 0.98 & 0.98 & 1.00 \\
\hline 2011 & & 1.00 & 0.98 & 0.98 & 0.96 & 0.96 & 0.99 \\
\hline 2012 & & & 1.00 & 0.98 & 0.95 & 0.96 & 0.98 \\
\hline 2013 & & & & 1.00 & 0.96 & 0.97 & 0.99 \\
\hline 2014 & & & & & 1.00 & 0.98 & 0.98 \\
\hline 2015 & & & & & & 1.00 & 0.99 \\
\hline 2016 & & & & & & & 1.00 \\
\hline LENG (\%) & 6.80 & 16.60 & 11.00 & 18.70 & 13.24 & 19.20 & 14.40 \\
\hline
\end{tabular}

(1)LENG, relative contribution of the sum of squares related to trait stem length.

Table 5. Ordering of sugarcane genotypes by genotypic value free from the interaction between crop years $(\mathrm{u}+\mathrm{g})$, genotypic values added of an average effect of interaction between crop years $(\mathrm{u}+\mathrm{g}+\mathrm{gem})$ and predicted gains for the multi-trait phenotypic index (PI), representing the joint analysis regarding crop years.

\begin{tabular}{|c|c|c|c|c|c|c|c|c|}
\hline Ranking & Genotype & $\mathrm{u}+\mathrm{g}$ & $\begin{array}{l}\text { CG } \\
(\%)\end{array}$ & $\begin{array}{l}\text { IV } \\
(\%)\end{array}$ & $\mathrm{U}+\mathrm{G}+\mathrm{GEM}$ & $\begin{array}{c}\mathrm{CG} \mathrm{U}+\mathrm{G}+\mathrm{GEM} \\
(\%)\end{array}$ & $\begin{array}{c}\text { IG U+G+GEM } \\
(\%)\end{array}$ & $\begin{array}{l}\mathrm{RC} \text { of the sum } \\
\text { of squares (\%) }\end{array}$ \\
\hline 1 & $\mathrm{G}_{19}$ (IAC873396) & 3.24 & 29.68 & 29.68 & 3.28 & 31.28 & 31.28 & 6.00 \\
\hline 2 & $\mathrm{G}_{8}$ (Nova Iraí) & 2.98 & 24.40 & 19.13 & 3.00 & 25.72 & 20.16 & 7.00 \\
\hline 3 & $\mathrm{G}_{1}$ (IACSP93-6006) & 2.96 & 22.38 & 18.34 & 2.98 & 23.59 & 19.33 & 5.70 \\
\hline 4 & $\mathrm{G}_{20}(\mathrm{RB} 835089)$ & 2.82 & 20.01 & 12.91 & 2.84 & 21.09 & 13.60 & 4.70 \\
\hline 5 & $\mathrm{G}_{3}(\mathrm{IAC} 87-3396)$ & 2.72 & 17.77 & 8.78 & 2.73 & 18.72 & 9.25 & 5.50 \\
\hline 6 & $\mathrm{G}_{2}$ (IAC91-2218) & 2.62 & 15.63 & 4.94 & 2.63 & 16.47 & 5.20 & 3.90 \\
\hline 7 & $\mathrm{G}_{13}$ (NA 56792) & 2.58 & 13.88 & 3.39 & 2.59 & 14.63 & 3.57 & 4.00 \\
\hline 8 & $\mathrm{G}_{9}$ (Ligeirinha Roxa) & 2.56 & 12.46 & 2.49 & 2.56 & 13.13 & 2.62 & 4.20 \\
\hline 9 & $\mathrm{G}_{5}(\mathrm{IAC} 91-2195)$ & 2.52 & 11.18 & 0.93 & 2.52 & 11.78 & 0.98 & 3.80 \\
\hline 10 & $\mathrm{G}_{14}$ (IAC915035) & 2.52 & 10.15 & 0.90 & 2.52 & 10.69 & 0.95 & 5.20 \\
\hline 11 & $\mathrm{G}_{4}(\mathrm{IAC} 91-5155)$ & 2.46 & 9.10 & -1.37 & 2.46 & 9.59 & -1.44 & 7.30 \\
\hline 12 & $\mathrm{G}_{18}$ (Palhuda) & 2.46 & 8.22 & -1.44 & 2.46 & 8.67 & -1.51 & 4.80 \\
\hline 13 & $\mathrm{G}_{17}($ Pingo de Mel) & 2.43 & 7.37 & -2.91 & 2.42 & 7.76 & -3.07 & 4.80 \\
\hline 14 & $\mathrm{G}_{10}$ (Pernambucana) & 2.41 & 6.60 & -3.37 & 2.41 & 6.95 & -3.55 & 5.50 \\
\hline 15 & $\mathrm{G}_{7}(\mathrm{RB} 85506)$ & 2.39 & 5.88 & -4.15 & 2.39 & 6.20 & -4.37 & 4.60 \\
\hline 16 & $\mathrm{G}_{15}$ (Preguiç̧osa) & 2.32 & 5.08 & -6.96 & 2.31 & 5.35 & -7.34 & 5.90 \\
\hline 17 & $\mathrm{G}_{16}$ (Tucumã) & 2.29 & 4.30 & -8.20 & 2.28 & 4.53 & -8.64 & 4.10 \\
\hline 18 & $\mathrm{G}_{12}(\mathrm{RB} 785750)$ & 2.27 & 3.55 & -9.09 & 2.26 & 3.75 & -9.58 & 3.90 \\
\hline 19 & $\mathrm{G}_{21}(\mathrm{RB} 765418)$ & 1.99 & 2.30 & -20.30 & 1.96 & 2.42 & -21.39 & 2.80 \\
\hline 20 & $\mathrm{G}_{6}(\mathrm{RB} 855453)$ & 1.98 & 1.15 & -20.70 & 1.95 & 1.21 & -21.81 & 2.60 \\
\hline 21 & $\mathrm{G}_{11}(\mathrm{SP} 716163)$ & 1.92 & 0.00 & -22.99 & 1.89 & 0.00 & -24.22 & 3.40 \\
\hline
\end{tabular}

$\mathrm{CG}$, cumulative gain over the overall mean; IG, individual gain over the overall mean; $\mathrm{CG} u+\mathrm{g}+\mathrm{gem}$, over the overall mean; IG u+g+gem, over the overal mean; RC, relative contribution. 
$\mathrm{u}+\mathrm{g}+$ gem were higher than gains obtained through effects $\mathrm{u}+\mathrm{g}$ (Table 5). The multivariate BLUP allows of the identification of superior genotypes, minimizing the distortions induced by oscillations of crop years and growing environments, since it method capitalizes the average effects among crop years $(\mathrm{u}+\mathrm{g}+\mathrm{gem})$. This result shows the usefulness of the mixed model method and the REML/BLUP procedures to carry out the genetic selections in a sugarcane-breeding program.

The estimates MHVG, PRVG, stability, and MHPRVG*MG showed similarity and ranked the three best genotypes: 'IAC873396', 'Nova Iraí', and 'IACSP 93-6006' (Table 6). Therefore, irrespectively of the crop year, these are high-yielding genotypes for total yield of stem and production of total soluble sugars, besides being phenotypically stable and adapted to the tested region. The other genotypes showed some distortions through the different techniques of ranking based on harmonic means by genotypic values.

Genotypes organized through the MHPRVG*MG are ideal to indicate the best genotypes at the end of the selection generations, as it simultaneously considers stability, adaptability, and yield of the genotypes throughout different evaluations or crop years. In the present study, the use of this multivariate approach, expanded to five traits, enabled this method to select the best genotypes. The genetic index (GI) was composed by the multi-trait (PI) and four auxiliary traits that were weighted by their accuracy, broadsense heritability, and genetic correlations.

The multi-trait selection using a genetic index (GI) allowed of the selection of four superior genotypes for total stem yield and production of total soluble sugars (PI), as follows: 'IAC873396', 'Nova Iraí', 'IACSP 936006', and 'RB 835089'. In contrast, when promoting the estimates of a multivariate BLUP, by weighing the accuracies, genetic correlations, and heritabilities, it was possible to isolate unrecognized biases and to select four genotypes, which resulted in the $11.05 \%$ gain, outperforming the overall mean of the genetic index. The selective accuracy of GI was 0.83 , with a superiority of $73.49 \%$ of the multi-trait PI that showed 0.61 of individual accuracy. A differential ranking of the genotypes selected by the multi-trait PI was observed in the selection by the genetic index (GI). Therefore, the genotype ordering through the genetic index (GI) may be

Table 6. Estimate ranking for stability (MHVG), adaptability (PRVG), simultaneous expression of stability, and adaptability (MHPRVG*MG) for the multi-trait phenotypic index (PI).

\begin{tabular}{|c|c|c|c|c|c|c|c|c|}
\hline \multicolumn{3}{|c|}{ Stability } & \multicolumn{3}{|c|}{ Adaptability } & \multicolumn{3}{|c|}{ Stability and adaptability } \\
\hline Ranking & Genotype & MHVG & Genotypes & PRVG & PRVG*MG & Genotypes & MHPRVG & MHPRVG*MG \\
\hline 1 & IAC873396 & 1.9 & IAC873396 & 2.5 & 6.24 & IAC873396 & 1.62 & 4.05 \\
\hline 2 & Nova Iraí & 1.5 & Nova Iraí & 1.98 & 4.96 & Nova Iraí & 1.48 & 3.69 \\
\hline 3 & IACSP93-6006 & 1.44 & IACSP93-6006 & 1.92 & 4.78 & IACSP93-6006 & 1.45 & 3.61 \\
\hline 4 & RB 835089 & 1.2 & RB 835089 & 1.65 & 4.12 & RB 765418 & 1.44 & 3.59 \\
\hline 5 & IAC $87-3396$ & 0.99 & IAC $87-3396$ & 1.43 & 3.58 & RB 855453 & 1.4 & 3.5 \\
\hline 6 & Tucumã & 0.92 & IAC91-2218 & 1.24 & 3.11 & RB 835089 & 1.35 & 3.37 \\
\hline 7 & IAC91-2218 & 0.78 & NA 56792 & 1.16 & 2.9 & SP716163 & 1.3 & 3.25 \\
\hline 8 & NA 56792 & 0.69 & Ligeirinha Roxa & 1.12 & 2.8 & IAC 87-3396 & 1.26 & 3.16 \\
\hline 9 & Ligeirinha Roxa & 0.64 & IAC915035 & 1.05 & 2.63 & Preguiçosa & 1.22 & 3.04 \\
\hline 10 & IAC915035 & 0.55 & IAC91-2195 & 1.04 & 2.61 & IAC91-2218 & 1.18 & 2.94 \\
\hline 11 & IAC91-2195 & 0.53 & Palhuda & 0.93 & 2.32 & NA 56792 & 1.13 & 2.82 \\
\hline 12 & IAC91-5155 & 0.37 & IAC91-5155 & 0.93 & 2.31 & Ligeirinha Roxa & 1.1 & 2.74 \\
\hline 13 & Palhuda & 0.36 & Pernambucana & 0.84 & 2.09 & IAC915035 & 1.05 & 2.62 \\
\hline 14 & RB 785750 & 0.29 & Pingo de Mel & 0.83 & 2.07 & IAC91-2195 & 1.04 & 2.6 \\
\hline 15 & Pingo de Mel & 0.2 & RB 85506 & 0.79 & 1.97 & Palhuda & 0.91 & 2.29 \\
\hline 16 & Pernambucana & 0.2 & Preguiçosa & 0.66 & 1.64 & IAC91-5155 & 0.91 & 2.28 \\
\hline 17 & RB 85506 & 0.08 & Tucumã & 0.59 & 1.46 & Tucumã & 0.81 & 2.03 \\
\hline 18 & Preguiçosa & -0.92 & RB 785750 & 0.55 & 1.38 & Pingo de Mel & 0.74 & 1.85 \\
\hline 19 & RB 765418 & -1.48 & RB 765418 & -0.02 & -0.05 & Pernambucana & 0.72 & 1.79 \\
\hline 20 & RB 855453 & -1.58 & RB 855453 & -0.05 & -0.12 & RB 785750 & 0.56 & 1.4 \\
\hline 21 & SP716163 & -2.14 & SP716163 & -0.16 & -0.39 & RB 85506 & 0.43 & 1.08 \\
\hline
\end{tabular}


considered for the final recommendation of genotypes, as GI is more accurate than a phenotypic multi-trait, since it aggregates information of the auxiliary traits, genotypic correlations, and genotypic values, increasing the selection reliability for sugarcane breeding.

\section{Conclusions}

1. The use of the multivariate best linear unbiased predictor (BLUP) method increases the selection gains, accuracy, and reliability of predictions for sugarcane breeding.

2. The high efficiency of selection with the use of the BLUP method for multi-trait selection is reached with more than eight measurements.

3. The multi-trait selection for total stem yield and production of total soluble sugars is efficient to define the superiority of genotypes regardless of the crop year.

\section{References}

ACOMPANHAMENTO DA SAFRA BRASILEIRA [DE] CANA-DE-AÇÚCAR: safra 2016/17: segundo levantamento, v.3, n.2, ago. 2016. Available at: <https://www.conab.gov.br/infoagro/safras/cana/boletim-da-safra-de-cana-de-acucar?start=10> Accessed on: Oct. 82019.

CARVALHO, I.R.; NARDINO, M.; DEMARI, G.H.; PELEGRIN, A.J. de; FERRARI, M.; SZARESKI, V.J.; OLIVEIRA, V.F. de; BARBOSA, M.H.; SOUZA, V.Q. de; OLIVEIRA, A.C. de; MAIA, L.C. da. Components of variance and interrelation of important traits for maize (Zea mays) breeding. Australian Journal Crop Science, v.11, p.982-988, 2017. DOI: https://doi.org/10.21475/ajcs.17.11.08.pne474.

CRUZ, C.D. GENES: a software package for analysis in experimental statistics and quantitative genetics. Acta Scientiarum. Agronomy, v.35, p.271-276, 2013. DOI: https://doi.org/10.4025/actasciagron.v35i3.21251.

DELlA BRUNA, E.; MORETO, A.L.; DALBÓ, M.A. Uso do coeficiente de repetibilidade na seleção de clones de pessegueiro para o litoral sul de Santa Catarina. Revista Brasileira de Fruticultura, v.34, p.206-215, 2012. DOI: https://doi.org/10.1590/ S0100-29452012000100028.

EEUWIJK, F.A. van; BUSTOS-KORTS, D.; MILLET, E.J.; BOERA, M.P.; KRUIJER, W.; THOMPSON, A.; MALOSETTI, M.; IWATA, H.; QUIROZ, R.; KUPPE, C.; MULLER, O.; BLAZAKIS, K.N.; YU, K.; TARDIEU, F.; CHAPMAN, S.C. Modelling strategies for assessing and increasing the effectiveness of new phenotyping techniques in plant breeding. Plant Science, v.282, p.23-39, 2019. DOI: https://doi.org/10.1016/j. plantsci.2018.06.018.
FAO. Food and Agriculture Organization of the United Nations. Faostat: statistics. Available at: $<$ http://www.fao.org/statistics/>. Accessed on: Oct. 82017.

HENDERSON, C.R. Best linear unbiased estimation and prediction under a selection model. Biometrics, v.31, p.423-447, 1975. DOI: https://doi.org/10.2307/2529430.

NEUPANE, J.; GUO, W. Agronomic basis and strategies for precision water management: a review. Agronomy, v.9, art.87, 2019. DOI; https://doi.org/10.3390/agronomy 9020087.

NUNES, A.C.P.; RESENDE, M.D.V. de; SANTOS, G.A. dos; ALVES, R.S. Evaluation of different selection indices combining Pilodyn penetration and growth performance in Eucalyptus clones. Crop Breeding and Applied Biotechnology, v.17, p.206213, 2017. DOI: https://doi.org/10.1590/1984-70332017v17n3a32.

PELEGRIN, A.J. de; CARVALHO, I.R.; NUNES, A.C.P.; DEMARI, G.H.; SZARESKI, V.J.; BARBOSA, M.H.; ROSA, T.C.; FERRARI, M.; NARDINO, M.; SANTOS, O.P. dos; RESENDE, M.D.V. de; SOUZA, V.Q. de; OLIVEIRA, A.C. de; MAIA, L.C. da. Adaptability, stability and multivariate selection by mixed models. American Journal of Plant Sciences, v.8, p.3324-3337, 2017. DOI: https://doi.org/10.4236/ajps.2017.813224.

R CORE TEAM. R: a language and environment for statistical computing. Vienna: R Foundation for Statistical Computing, 2015.

RAMALHO, M.A.P.; SANTOS, J.B. dos; PINTO, C.A.B.P.; SOUZA, E.A. de; GONÇALVES, F.M.A.; SOUZA, J.C. de. Genética na agropecuária. 5.ed. rev. Lavras: UFLA, 2012. 566p.

RESENDE, M.D.V. de. SELEGEN-REML/BLUP: sistema estatístico e seleção genética computadorizada via modelos lineares mistos. Colombo: Embrapa Florestas, 2007. 359p.

RESENDE, M.D.V. de; DUARTE, J.B. Precisão e controle de qualidade em experimentos de avaliação de cultivares. Pesquisa Agropecuária Tropical, v.37, p.182-194, 2007.

SANTOS, H.G. dos; JACOMINE, P.K.T.; ANJOS, L.H.C. dos; OLIVEIRA, V.A. de LUMBRERAS, J.F.; COELHO, M.R.; ALMEIDA, J.A. de; ARAUJO FILHO, J.C. de; OLIVEIRA, J.B. de; CUNHA, T.J.F. Sistema brasileiro de classificação de solos. 5.ed. rev. e ampl. Brasília: Embrapa, 2018. 356p.

SILVA, J.P.N. da; SILVA, M.R.N. da. Noções da cultura da canade-açúcar. Inhumas: IFG; Santa Maria: Universidade Federal de Santa Maria, 2012. 105p.

VIANA, A.P.; RESENDE, M.D.V. de. Genética quantitativa no melhoramento de fruteiras. Rio de Janeiro: Interciência, 2014. 282 p.

VITTORAZZI, C.; AMARAL JUNIOR, A.T.; GUIMARÃES, A.G.; VIANA, A.P.; SILVA, F.H.L.; PENA, G.F.; DAHER, R.F.; GERHARDT, I.F.S.; OLIVEIRA, G.H.F.; PEREIRA, M.G. Indices estimated using REML/BLUP and introduction of a super-trait for the selection of progenies in popcorn. Genetics and Molecular Research, v.16, gmr16039769, 2017. DOI: https://doi.org/10.4238/gmr16039769.

Pesq. agropec. bras., Brasília, v.55, e00518, 2020

DOI: 10.1590/S1678-3921.pab2020.v55.00518 